\title{
Teaching Video NeuroImages: Vagoglossopharyngeal neuralgia mimicking a seizure
}

Albi J. Chalissery, MRCPI, Maria Gaughan, MRCPI, Geoffrey Haughton, Gerard Mullins, MRCPI, and Norman Delanty, FRCPI

Neurology ${ }^{\circledR}$ 2018;90:e1179. doi:10.1212/WNL.0000000000005211

A 79-year-old woman with a history of partial thyroidectomy for multinodular goiter presented with acute onset episodic left ear pain followed by collapse with loss of awareness and limb jerking. Video EEG captured stereotyped episodes (video, links.lww.com/WNL/A287) with corresponding bradycardia and asystole for several seconds without ictal changes. A diagnosis of vagoglossopharyngeal neuralgia was made. She became symptom-free with eslicarbazepine and pacemaker insertion.

Approximately $10 \%$ of patients with glossopharyngeal neuralgia experience bradycardia and syncope. ${ }^{1}$ Activation of the vagus nerve (dorsal motor nucleus) by excessive input from the glossopharyngeal nerve (via tractus solitarius) may lead to potential cardiac arrhythmias. ${ }^{2}$

\section{Author contributions}

All authors had access to and contributed to the manuscript. Albi Chalissery and Maria Gaughan: manuscript writing/revision. Geoffrey Haughton: video editing. Gerard Mullins and Norman Delanty: manuscript revision.

\section{Study funding}

No targeted funding reported.

\section{Disclosure}

The authors report no disclosures relevant to the manuscript. Go to Neurology.org/ $\mathrm{N}$ for full disclosures.

\section{References}

1. Blumenfeld A, Nikolskaya G. Glossopharyngeal neuralgia. Curr Pain Headache Rep 2013;17:343.

2. Varrasi C, Strigaro G, Prandi P, et al. Complex pattern of convulsive syncope in glossopharyngeal neuralgia: video/EEG report and short review. Epilepsy Behav 2011;20:407-409.
Correspondence

A.J. Chalissery

albi.chalissery@hse.ie

\section{MORE ONLINE}

$\rightarrow$ Video

links.lww.com/WNL/A287

$\rightarrow$ Download Teaching slides:

links.lww.com/WNL/A288 


\section{Neurology}

Teaching Video NeuroImages: Vagoglossopharyngeal neuralgia mimicking a seizure Albi J. Chalissery, Maria Gaughan, Geoffrey Haughton, et al. Neurology 2018;90;e1179

DOI 10.1212/WNL.0000000000005211

This information is current as of March 26, 2018

\section{Updated Information \&} Services

References

Subspecialty Collections

Permissions \& Licensing

Reprints including high resolution figures, can be found at: http://n.neurology.org/content/90/13/e1179.full

This article cites 2 articles, 0 of which you can access for free at: http://n.neurology.org/content/90/13/e1179.full\#ref-list-1

This article, along with others on similar topics, appears in the following collection(s):

All Epilepsy/Seizures

http://n.neurology.org/cgi/collection/all_epilepsy_seizures All Headache

http://n.neurology.org/cgi/collection/all_headache

Video/ EEG use in epilepsy

http://n.neurology.org/cgi/collection/video_eeg_use_in_epilepsy

Information about reproducing this article in parts (figures,tables) or in its entirety can be found online at:

http://www.neurology.org/about/about_the_journal\#permissions

Information about ordering reprints can be found online:

http://n.neurology.org/subscribers/advertise

Neurology ${ }^{\circledR}$ is the official journal of the American Academy of Neurology. Published continuously since 1951, it is now a weekly with 48 issues per year. Copyright () 2018 American Academy of Neurology. All rights reserved. Print ISSN: 0028-3878. Online ISSN: 1526-632X.

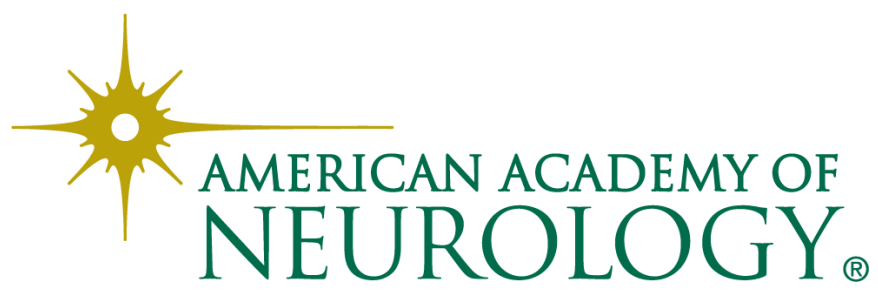

